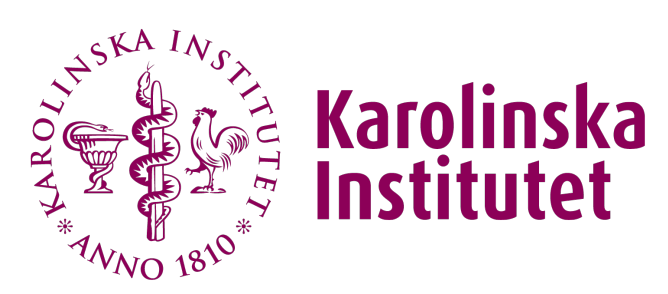

Karolinska Institutet

http://openarchive.ki.se

This is a Peer Reviewed Accepted version of the following article, accepted for publication in Social Neuroscience.

2014-06-30

\title{
Associations between oxytocin-related genes and autistic-like traits
}

Johansson, Daniel; Zettergren, Anna; Jonsson, Lina; Melke, Jonas; Anckarsäter, Henrik; Lichtenstein, Paul; Westberg, Lars

Soc Neurosci. 2014;9(4):378-86.

http://doi.org/10.1080/17470919.2014.897995

http://hdl.handle.net/10616/42116

If not otherwise stated by the Publisher's Terms and conditions, the manuscript is deposited under the terms of the Creative Commons Attribution-NonCommercial-NoDerivatives License (http://creativecommons.org/licenses/by-nc-nd/4.0/), which permits non-commercial re-use, distribution, and reproduction in any medium, provided the original work is properly cited, and is not altered, transformed, or built upon in any way. 


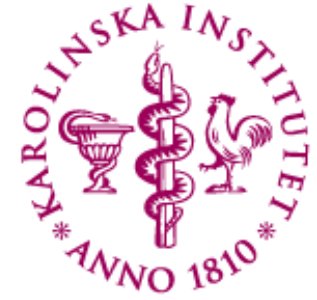 \\ Karolinska \\ Institutet}

This is an author-produced version of a paper published by Social Neuroscience. This paper has been peer-reviewed but does not include the final publisher proof-corrections or journal pagination.

Associations between oxytocin-related genes and autisticlike traits.

Johansson, Daniel; Zettergren, Anna; Jonsson, Lina; Melke, Jonas; Anckarsäter, Henrik; Lichtenstein, Paul; Westberg, Lars

Soc Neurosci. 2014 Aug;9(4):378-86. Epub 2014 Mar 17.

DOI: $10.1080 / 17470919.2014 .897995$

Access to the published version may require subscription. Published with permission from: Taylor \& Francis 


\section{ASSOCIATIONS BETWEEN OXYTOCIN-RELATED GENES AND AUTISTIC-LIKE TRAITS.}

Daniel Johansson ${ }^{1}$, Anna Zettergren ${ }^{1}$, Lina Jonsson ${ }^{1}$, Jonas Melke ${ }^{1}$, Henrik Anckarsäter ${ }^{2}$, Paul Lichtenstein $^{3}$ and Lars Westberg ${ }^{1}$

${ }^{1}$ Department of Pharmacology, Institute of Neuroscience and Physiology, The Sahlgrenska Academy, University of Gothenburg, POB 431, 40530 Gothenburg, Sweden.

${ }^{2}$ Department of Forensic Psychiatry, Institute of Neuroscience and Psychology, The Sahlgrenska Academy, University of Gothenburg, 42250 Gothenburg, Sweden. Email:

henrik.anckarsater@neuro.gu.se.

${ }^{3}$ Department of Medical Epidemiology and Biostatistics, Karolinska Institutet, POB 281, 17177 Stockholm, Sweden. Email: paul.lichtenstein@ki.se.

Corresponding author: Daniel Johansson, Department of Pharmacology, Institute of Neuroscience and Physiology at The Sahlgrenska Academy, University of Gothenburg, POB 431, 40530 Gothenburg, Sweden. Phone number: +46-(0)31-7866461. E-mail: daniel.johansson@neuro.gu.se. 


\begin{abstract}
Oxytocin has repeatedly been shown to influence human behavior in social contexts; also, a relationship between oxytocin and the pathophysiology of Autism Spectrum Disorder (ASD) has been suggested. In the present study, we investigated SNPs in the oxytocin gene (OXT), and the genes for single-minded 1 (SIM1), aryl hydrocarbon receptor nuclear translocator 2 (ARNT2), and cluster of differentiation 38 (CD38), in a population of 1771 children from the Child and Adolescent Twin Study in Sweden. Statistical analyses were performed to investigate any association between SNPs and autistic-like traits (ALTs), measured through ASD scores in the Autism-Tics, ADHD and other Comorbidities inventory. Our main finding was a statistically significant association between the SIM1 SNP rs3734354 (Pro352Thr) and ASD scores for language impairment ( $\mathrm{p}=0.0004)$. Furthermore, nominal associations were found between ASD scores and SNPs in OXT, ARNT2 and CD38. In summary, the present study lends support to the hypothesis that oxytocin and oxytocin neuron development may have an influence on the development of ALTs, and suggests a new candidate gene in the search for the pathophysiology of ASD.
\end{abstract}

Keywords: Autism, SNP, oxytocin, ARNT2, SIM1, CD38

Highlights:

- We examined SNPs in oxytocin-related genes, in relation to autistic-like traits

- A SIM1 SNP was associated with autistic-like traits, primarily language impairment

- SNPs in OXT, ARNT2 and CD38 showed nominal associations with autistic-like traits 


\section{Introduction}

Patients with Autism Spectrum Disorder (ASD) are characterized by three core symptom dimensions: language impairment, impairment of social interaction and communication, and restrictive and repetitive behavior (American Psychiatric Association. and American Psychiatric Association. Task Force on DSM-IV., 1994). Studies of autistic-like traits (ALTs) have suggested that an ASD diagnosis represents the extreme lower end of normally distributed abilities for social communication (Constantino et al., 2004; Posserud et al., 2006). The importance of genetic factors in the etiology of ASD has repeatedly been demonstrated in twin studies, with heritability estimates of 70-90\% (Bailey et al., 1995; Lichtenstein et al., 2010; Rosenberg et al., 2009). Moreover, ALTs and ASD have been shown to share common genetic influences (Lundstrom et al., 2012; Robinson et al., 2011). The theoretical division into the three symptom dimensions mentioned above has been confirmed in several studies (Happe and Ronald, 2008), and these domains have been indicated to have partly separate genetic influences when investigated in the general population (Ronald et al., 2011). Furthermore, it has been demonstrated that girls and boys display different ALTs, both among ASD patients (Mandy et al., 2012) and among children who do not meet diagnostic criteria for ASD (Dworzynski et al., 2012).

Oxytocin is a neuropeptide primarily produced in magnocellular neurons of the paraventricular (PVN) and supraoptic nuclei (SON) of the hypothalamus. The major part of oxytocin is transported to the posterior pituitary, where it is released into the general circulation, but a smaller part is released into the brain via magnocellular dendrites (Ludwig and Leng, 2006) and oxytocin-releasing neurons projecting to specific brain areas, including the amygdala (Knobloch et al., 2012). Oxytocin has, aside from its established roles in lactation and parturition, been implicated in regulation of social behavior (Donaldson and Young, 2008). In rodents, oxytocin is involved in social interaction, social recognition, pair bonding and maternal behavior (Neumann, 2008). Several studies have been conducted under the hypothesis that this influence also exists in humans, and oxytocin has been shown to be associated with face recognition and formation of affiliative bonds (Lee et al., 2009), and concentrations of oxytocin in cerebrospinal fluid of newborns have showed a positive correlation with 
interest in social engagement with others (Clark et al., 2013). The suggestion that oxytocin plays a role in human social interaction has inspired the hypothesis that it may also be involved in the phenotypes of ASD, and it has been shown that plasma oxytocin levels in children with autism are lower than in controls (Modahl et al., 1998). Additionally, adults with classic autism and Asperger's syndrome, given intravenous infusions of oxytocin, experience reduced number and severity of repetitive behaviors (Hollander et al., 2003) and increased ability to remember affective components of spoken words (Hollander et al., 2007). Intranasally administered oxytocin has been shown to increase emotion recognition in young patients with ASD (Guastella et al., 2010) and to improve social cognition (Anagnostou et al., 2012) and influence amygdala activation in the processing of facial stimuli in ASD patients (Domes et al., 2013). Furthermore, several studies have indicated that single nucleotide polymorphisms (SNPs) in the oxytocin (OXT) and oxytocin receptor genes are associated with ASD (Ebstein et al., 2012).

Single-minded 1 (SIM1) is a transcription factor required for the terminal differentiation of neuroendocrine neurons in the PVN and SON (Michaud et al., 1998). It has so far been studied mainly with a focus on hyperphagia and obesity, with an effect demonstrated by mice haploinsufficient for the SIM1 gene (Xi et al., 2012). It has been shown that SIM1 is important for oxytocin expression in the PVN, with a near $80 \%$ reduction in haploinsufficient mice (Kublaoui et al., 2008). In the PVN and SON, SIM1 is co-expressed with the transcription factor aryl hydrocarbon receptor nuclear translocator 2 (ARNT2). The loss of ARNT2 function also affects the development of the same neuroendocrine cell lines within the PVN and SON influenced by SIM1 (Michaud et al., 2000). Interestingly, SNPs in the human ARNT2 gene have been associated with ASD (Chakrabarti et al., 2009).

Cluster of differentiation $38(\mathrm{CD} 38)$ is a type II transmembrane protein associated with normal social behavior in mice (Jin et al., 2007), and has been shown to play an important role in the process of oxytocin release in the hypothalamus in mice, with CD38 disruption yielding impairment of maternal behavior and social recognition, similar to the behavior seen in OXT knockout mice (Higashida et al., 
2011). In humans, there have been indications that SNPs in the CD38 gene are associated with reduced oxytocin plasma levels and ASD symptoms, as well as effects on visual processing of, and fusiform gyrus activation by, social stimuli (Munesue et al., 2010; Sauer et al., 2012).

In this study, we considered the above genes (OXT, SIM1, ARNT2 and CD38) as possible candidate genes influencing ALTs in the general population, given the implications for a possible oxytocin influence on the symptoms of ASD, and the potential influence of the genes SIM1, ARNT2, and CD38 on oxytocin release and neuron development. 


\section{Methods and Materials}

\section{Participants}

The Child and Adolescent Twin Study in Sweden (CATSS) is an ongoing study since July 2004 that targets all twins born in Sweden since July 1992, at 9 or 12 years of age. The study has a response rate of $80 \%$, making it a highly representative population sample (Anckarsater et al., 2011). At present, data has been collected on 12,446 children: $\mathrm{n}=5,944$ 9-year-olds and 6496 12-year-olds. The present study used genetic material from the first DNA collection from CATSS (both 9- and 12-year-olds), including information on a total of 1771 individuals from the CATSS population ( 887 girls and 884 boys). This cohort has been used in previous genetic association studies (Walum et al., 2012). Since the sample was recruited from the general population, it contains the full variation of ALTs, including those meeting the criteria for a clinical diagnosis of ASD and other neuropsychiatric disorders. The focus of our study was to investigate the possible influence of common genetic variations in $O X T$, SIM1, CD38 and ARNT2 on ALTs - hence, 24 individuals were excluded from the analyses due to either documented brain damage (most commonly cerebral palsy) or a known genetic syndrome (most commonly Down syndrome but also Fragile X syndrome), since individuals with these conditions are known to display a high degree of autism-related symptoms (Zafeiriou et al., 2007). The final number of individuals used in the statistical analyses ( $n=1747)$ included 357 monozygotic (MZ) twin pairs, 500 dizygotic (DZ) twin pairs and 33 individuals without their co-twin. Zygosity was determined using a panel of 47 SNPs (Hannelius et al., 2007). Although all statistical analyses (see below) were adjusted for kinship, the population is analyzed as a representative sample of children from the general population in Sweden. The CATSS study has been approved by the Karolinska Institutet Ethical Review Board (No. 02-289), and informed consent was provided by all participants. The present study was carried out in accordance with The Code of Ethics of the World Medical Association (Declaration of Helsinki) for experiments involving humans.

\section{Measurements}

The parents of all twins were contacted when their twins turned 9 or 12 years old, and asked to participate in a telephone interview containing, among other instruments, the Autism-Tics, ADHD and 
other Co-morbidities inventory (A-TAC) (Hansson et al., 2005; Larson et al., 2010). The A-TAC is a tool for screening general populations for child ASD and related conditions, and can also be used as a dimensional measure of ALTs, reflecting the continuous character of the autism spectrum. It has a high sensitivity and specificity ( 0.96 and 0.88 , respectively) for predicting a clinical diagnosis of ASD (Hansson et al., 2005; Larson et al., 2010). The 17 questions on ALTs, 12 of which specifically address the DSM-IV criteria for autistic disorder, reflect the three core symptom dimensions of autism, represented as modules: language impairment (six questions), social interaction impairment (six questions) and restrictive/repetitive behavior (five questions). Each item has three response categories: "No" (coded 0), "Yes, to some extent" (coded 0.5) and "Yes" (coded 1). The measure of total ASD scores is the sum of the 17 items. The A-TAC is freely available from the Internet as an appendix to the published article by Larson et al. (Larson et al., 2010). It has previously been used as a dimensional measure of ALTs in a genetic association study (Walum et al., 2012), and in several studies investigating the heritability of (Lundstrom et al., 2012), and relation between, different neurodevelopmental and behavioral problems in children from the general population (Lichtenstein et al., 2010; Lundstrom et al., 2011).

\section{Genotyping}

DNA was extracted from saliva samples using OraGene ${ }^{\circledR}$ DNA self-collection kit (DNA Genotek, Inc., Ottawa, Ontario, Canada). Nine single nucleotide polymorphisms (SNPs) in OXT, SIM1, ARNT2 and CD38 were genotyped with KASPar ${ }^{\circledR}$ PCR SNP genotyping system (KBiosciences, Herts, UK). The SNPs were chosen based on previous results from genetic association studies on ASD and related phenotypes, in an attempt to further investigate these in relation to ALTs, with the exception of rs3734354 (SIM1), rs4072568 (ARNT2), and rs6449182 (CD38), which were chosen based on their relationship to oxytocin regulation and that these particular SNPs have been shown to be functional (Jamroziak et al., 2009; Swarbrick et al., 2011). The SNPs chosen for genotyping are listed in Table 1, with further information regarding positions, minor allele frequencies (MAF) and the previous studies reporting associations with ASD symptoms, or SNP effects on functionality. The genotyping success 
rate was $>97 \%$. All the SNPs were found to be in Hardy-Weinberg equilibrium ( $p>0.05)$, which was calculated using one subject in each monozygotic twin pair and all of the dizygotic twins.

\section{Statistical Analyses}

Statistical associations between SNPs and continuous measures of ALTs, including the A-TAC modules for language impairment, social interaction impairment, and restricted and repetitive behavior, were estimated using a linear mixed effect model in the MIXED procedure (PROC MIXED) of SAS 9.3 (SAS Institute, Inc., Cary, NC, USA). This model allows adjustment for the dependent nature of the twin observations (i.e. A-TAC scores from all genotyped subjects were included in the analyses). Given that monozygotic twins, on average, share $100 \%$ of their genome while dizygotic twins only share $50 \%$ of their genome, and that monozygotic twins are more similar that dizygotic twins in ALT scores (Lundstrom et al., 2012), we modeled two separate variance-covariance matrices: (1) for monozygotic twins, and (2) for dizygotic twins. By using R-side random effects with an unstructured variance-covariance matrix, correlations between individuals in group (1) and (2) were calculated. The sample size made it possible to analyze girls and boys separately. Mean scores and standard deviations were calculated using the MEANS procedure (PROC MEANS) in SAS 9.3. To control for multiple testing, Bonferroni correction was performed: analyses of nine SNPs, three module scores and two sexes separately, yielding 54 independent tests, resulting in a corrected p-value limit of 0.0009 


\section{Results}

Associations between SNPs and ALTs, or any of the modules for language impairment, social interaction impairment or restrictive/repetitive behavior, are shown in Table 2. The most significant result was found in boys, between the SIM1 SNP rs3734354 and total ASD scores, as well as social interaction impairment, and language impairment, where the T-allele homozygotes were shown to have higher scores. The association with language impairment $(\mathrm{p}=0.0004)$ survived Bonferroni correction. Based on the mean scores of the three genotypes, we assumed that the effect was recessive, and conducted a post-hoc analysis under a recessive model (TT vs. GT/GG), resulting in a p-value of 0.00009. In girls, the OXT SNP rs2770378 showed nominal association with total ASD scores, language impairment, and restricted behavior. These associations did not, however, survive correction for multiple testing. Nominal associations were also found for the SNPs rs3901896 in ARNT2 (risk allele T) and rs6449182 in CD38 (risk allele C). We found no significant associations with ALTs for SNPs rs2740204 (OXT), rs6133010 (OXT), rs3796863 (CD38), rs4072568 (ARNT2) or rs4778599 (ARNT2). 


\section{Discussion}

The main finding of the present study was an association between language impairment and the TT genotype of the SIM1 SNP rs3734354 in boys. This SNP was also nominally associated with total ASD scores and social interaction impairment. SIM1 has been previously studied for associations with obesity and hyperphagia, with a demonstrated lowering of hypothalamic oxytocin mRNA expression (Xi et al., 2012) and oxytocin peptide levels (Kublaoui et al., 2008) in SIM1 haploinsufficient mice. Swarbrick and co-workers extended these findings to humans by demonstrating that the T allele of rs 3734354 ) is associated with a $22 \%$ decreased transcriptional activity and the TT genotype to be associated with adiposity in males (Swarbrick et al., 2011). Taken together with our results these findings supports the view that the TT genotype of the SIM1 SNP rs3734354 contribute to lower oxytocin levels, which may have consequences for behavioral as well as for peripheral phenotypes. To our knowledge, our study is the first to investigate this SIM1 SNP with respect to continuous scores for ASD-related phenotypes. In previous GWAS studies, only one (Ronald et al., 2010) has investigated ASD in this manner, and this SNP was not genotyped by the array used in that study (Affymetrix 500K). Other GWA studies (Anney et al., 2012; Anney et al., 2010; Ma et al., 2009; Wang et al., 2009; Weiss et al., 2009), comparing diagnosed ASD patients with healthy controls, did indeed include rs3734354, and reported no associations at the GWAS level. Taken together with our results, this may indicate that SIM1 plays a part in ALTs, rather than effecting an actual diagnosis.

We also found nominally significant associations between the OXT SNP rs2770378 and ALTs for girls, specifically for the language impairment and restricted behavior modules. In previous studies, Chakrabarti et al. found an association between rs2770378 and ASD diagnosis (Chakrabarti et al., 2009), while Yrigollen et al., in contrast with our results, found no association with ASD on a number of assessment scales (Yrigollen et al., 2008). Neither of these studies performed sex-specific analyses. Furthermore, we were not able to replicate the association between rs2740204 and stereotypic behaviors presented by Yrigollen et al. in the above study, nor were we able to find any association between ALTs and the OXT SNP rs6133010, previously associated with ASD in a study by Ebstein et al. (Ebstein et al., 2009). 
It is somewhat puzzling that we were able to associate OXT with ALTs in girls, but SIM1 in boys, given that our hypothesis included SIM1 as a regulator of oxytocin neuron development. However, one may consider that SIM1 not only influences oxytocin neurons in the hypothalamus, but arginine vasopressin neurons as well (Duplan et al., 2009), and that it has been indicated that vasopressin activity is associated with social behavior, e.g. through influences on male parental behavior (Wang et al., 1998) and male pair bond formation in voles (Cho et al., 1999) and humans (Walum et al., 2012). Furthermore, a strong sexual dimorphism for the roles of oxytocin and vasopressin has been established, indicating a more important role of vasopressin in males for social recognition (de Vries, 2008). There is a possibility that this sexual dimorphism can explain the male-specific association of the SIM1 SNP, as well as the female-specific importance of OXT.

We also found significant effects of the ARNT2 SNP rs3901896 in girls on language impairment. Although this result did not survive correction for multiple testing, it has previously been investigated by Chakrabarti et al. (Chakrabarti et al., 2009) - albeit they found an association by a case-control analysis. We were not able to replicate their finding of the ARNT2 SNP rs4778599, where an association in their case was seen with scores on the Autism Spectrum Quotient scale.

Finally, we found an association between rs6449182 in CD38 and language impairment scores, not obviously specific for either gender. Two independent studies have shown that carriers of the G allele have higher CD38 mRNA transcript levels and a higher proportion of CD38-positive cells (Jamroziak et al., 2009; Polzonetti et al., 2012). A study by Riebold et al. suggested associations between CD38 transcription levels in general and IQ, as well as scores on the Vineland Adaptive Behavior Scales (specifically the scales for social skills and communication) (Riebold et al., 2011). If, indeed, the transcription levels are increased by the $\mathrm{G}$ allele, these two findings taken together would be in line with our results, where homozygotic carriers of the G allele scored lower for ALTs related to language impairment. We were not able to find any statistical association between ALTs and rs3796863, a CD38 SNP previously investigated by Munesue et al., finding an association with ASD in a clinical 
subset (Munesue et al., 2010), and Sauer et al., finding an association with fusiform gyrus activation (implicated in ASD research) (Sauer et al., 2012).

In conclusion, this study suggests an association between an exonic SIM1 SNP and ALTs in children from the general population. Given that the relevant homozygote variation mentioned above is relatively rare, however, further research is needed to support this before any conclusions may be drawn. Furthermore, we have extended previous investigations into SNPs from OXT, ARNT2 and CD38. However, the results are not conclusive, and should be interpreted with caution, as previous findings, as well as our results, may be coincidental. 


\section{Conflicts of interest}

The authors declare no conflicts of interest.

\section{Acknowledgements}

Funding for the study was provided by grants from the Swedish Research Council, Swedish Research Council for Working Life and Social Research, Swedish Brain Foundation, Svenska Sällskapet för Medicinsk Forskning (SSMF), Fredrik and Ingrid Thurings stiftelse, Åke Wibergs stiftelse, Åhlénstiftelsen, Jeanssons-stiftelsen, Magnus Bergvalls stiftelse, Söderström-Königska stiftelsen, Märta Lundqvists stiftelse and the Novo Nordisk Foundation. 
Table 1. SNP details

\begin{tabular}{lcllll}
\hline Gene & Chromosome & SNP & Location & MAF & Reference \\
\hline OXT & $20 p 13$ & rs2740204 & Downstream & $0.40(\mathrm{~T})$ & Yrigollen et al. 2008; Chakrabarti et al. 2009 \\
& & rs2770378 & Downstream & $0.40(\mathrm{~A})$ & Yrigollen et al. 2008; Chakrabarti et al. 2009 \\
& & rs6133010 & Upstream & $0.11(\mathrm{G})$ & Ebstein et al. 2009 \\
SIM1 & $6 \mathrm{q} 16.3$ & $\mathrm{rs} 3734354$ & Exon & $0.14(\mathrm{~T})$ & Swarbrick et al. 2011 \\
CD38 & $4 \mathrm{p} 15.32$ & $\mathrm{rs} 3796863$ & Intron & $0.31(\mathrm{~A})$ & Munesue et al. 2010, Sauer et al. 2012 \\
& & $\mathrm{rs} 6449182$ & Intron & $0.22(\mathrm{G})$ & Jamroziak et al. 2009, Riebold et al. 2011 \\
ARNT2 & \multirow{2}{*}{$15 \mathrm{q} 25.1$} & $\mathrm{rs} 3901896$ & Intron & $0.39(\mathrm{~T})$ & Chakrabarti et al. 2009 \\
& & $\mathrm{rs} 4072568$ & Exon & $0.20(\mathrm{~A})$ & Swarbrick et al. 2011 \\
& & $\mathrm{rs} 4778599$ & Intron & $0.33(\mathrm{~A})$ & Chakrabarti et al. 2009 \\
\hline
\end{tabular}


Table 2. Associations between SNPs in OXT and OXT-related genes and ALTs

\begin{tabular}{|c|c|c|c|c|c|c|c|c|c|c|c|c|c|}
\hline \multirow[t]{3}{*}{ SNP } & \multirow[b]{3}{*}{$\mathbf{n}$} & \multicolumn{3}{|c|}{ Total ASD symptoms } & \multicolumn{3}{|c|}{ Language impairment } & \multicolumn{3}{|c|}{ Social interaction impairment } & \multicolumn{3}{|c|}{ Restricted behaviour } \\
\hline & & \multicolumn{3}{|c|}{ Mean score (SD) } & \multicolumn{3}{|c|}{ Mean score (SD) } & \multicolumn{3}{|c|}{ Mean score (SD) } & \multicolumn{3}{|c|}{ Mean score (SD) } \\
\hline & & All & Boys & Girls & All & Boys & Girls & All & Boys & Girls & All & Boys & Girls \\
\hline \multirow[t]{4}{*}{ OXT rs2770378 } & $\mathrm{A} / \mathrm{A}(289)$ & $0.93(1.66)$ & $1.21(1.98)$ & $0.65(1.23)$ & $0.33(0.69)$ & $0.40(0.82)$ & $0.26(0.52)$ & $0.33(0.66)$ & $0.40(0.74)$ & $0.27(0.57)$ & $0.26(0.68)$ & $0.40(0.84)$ & $0.13(0.44)$ \\
\hline & $\mathrm{A} / \mathrm{G}(789)$ & $0.87(1.77)$ & $1.22(2.07)$ & $0.52(1.33)$ & $0.28(0.67)$ & $0.41(0.82)$ & $0.16(0.47)$ & $0.31(0.71)$ & $0.41(0.83)$ & $0.21(0.56)$ & $0.28(0.66)$ & $0.40(0.78)$ & $0.16(0.48)$ \\
\hline & $\mathrm{G} / \mathrm{G}(636)$ & $1.05(2.01)$ & $1.28(2.39)$ & $0.81(1.49)$ & $0.38(0.73)$ & $0.48(0.84)$ & $0.28(0.59)$ & $0.35(0.80)$ & $0.43(0.97)$ & $0.27(0.56)$ & $0.32(0.75)$ & $0.37(0.85)$ & $0.26(0.64)$ \\
\hline & $\mathrm{p}$ & 0.224 & 0.830 & 0.027 & 0.085 & 0.568 & 0.012 & 0.437 & 0.879 & 0.161 & 0.563 & 0.826 & 0.033 \\
\hline \multirow[t]{4}{*}{ SIM1 rs3734354 } & $\mathrm{G} / \mathrm{G}(1281)$ & $0.93(1.84)$ & $1.21(2.12)$ & $0.67(1.48)$ & $0.32(0.69)$ & $0.42(0.79)$ & $0.22(0.56)$ & $0.32(0.72)$ & $0.40(0.83)$ & $0.25(0.59)$ & $0.29(0.70)$ & $0.39(0.81)$ & $0.20(0.57)$ \\
\hline & $\mathrm{G} / \mathrm{T}(416)$ & $0.97(1.77)$ & $1.23(2.13)$ & $0.65(1.13)$ & $0.33(0.68)$ & $0.42(0.83)$ & $0.22(0.41)$ & $0.36(0.75)$ & $0.44(0.89)$ & $0.26(0.54)$ & $0.28(0.70)$ & $0.37(0.82)$ & $0.18(0.48)$ \\
\hline & $\mathrm{T} / \mathrm{T}(26)$ & $1.56(3.23)$ & $2.79(4.06)$ & $0.13(0.31)$ & $0.62(1.30)$ & $1.07(1.65)$ & $0.08(0.19)$ & $0.54(1.30)$ & $0.96(1.68)$ & $0.04(0.14)$ & $0.40(0.85)$ & $0.75(1.05)$ & $0(0)$ \\
\hline & $\mathrm{p}$ & 0.108 & 0.0035 & 0.388 & 0.019 & $0.0004 *$ & 0.592 & 0.160 & 0.019 & 0.490 & 0.580 & 0.180 & 0.534 \\
\hline \multirow[t]{4}{*}{ ARNT2 rs3901896 } & $\mathrm{C} / \mathrm{C}(633)$ & $0.95(1.79)$ & $1.40(2.31)$ & $0.55(0.99)$ & $0.33(0.73)$ & $0.51(0.94)$ & $0.16(0.41)$ & $0.33(0.70)$ & $0.45(0.88)$ & $0.22(0.47)$ & $0.30(0.67)$ & $0.45(0.83)$ & $0.17(0.43)$ \\
\hline & $\mathrm{C} / \mathrm{T}(825)$ & $0.93(1.89)$ & $1.13(2.12)$ & $0.73(1.61)$ & $0.30(0.64)$ & $0.35(0.70)$ & $0.25(0.58)$ & $0.34(0.79)$ & $0.42(0.90)$ & $0.27(0.64)$ & $0.29(0.73)$ & $0.37(0.82)$ & $0.21(0.61)$ \\
\hline & $\mathrm{T} / \mathrm{T}(257)$ & $1.01(1.87)$ & $1.20(2.04)$ & $0.75(1.58)$ & $0.41(0.79)$ & $0.50(0.88)$ & $0.29(0.64)$ & $0.32(0.67)$ & $0.37(0.75)$ & $0.25(0.54)$ & $0.28(0.70)$ & $0.34(0.75)$ & $0.20(0.63)$ \\
\hline & $\mathrm{p}$ & 0.903 & 0.502 & 0.409 & 0.269 & 0.150 & 0.046 & 0.805 & 0.742 & 0.839 & 0.747 & 0.443 & 0.808 \\
\hline \multirow[t]{4}{*}{ CD38 rs6449182 } & $\mathrm{C} / \mathrm{C}(1031)$ & $0.95(1.87)$ & $1.25(2.22)$ & $0.67(1.42)$ & $0.32(0.70)$ & $0.44(0.84)$ & $0.21(0.52)$ & $0.33(0.74)$ & $0.41(0.88)$ & $0.25(0.57)$ & $0.30(0.72)$ & $0.40(0.84)$ & $0.21(0.58)$ \\
\hline & $\mathrm{C} / \mathrm{G}(597)$ & $0.99(1.88)$ & $1.25(2.16)$ & $0.70(1.44)$ & $0.36(0.73)$ & $0.45(0.82)$ & $0.26(0.59)$ & $0.35(0.77)$ & $0.43(0.89)$ & $0.26(0.60)$ & $0.28(0.67)$ & $0.37(0.77)$ & $0.18(0.52)$ \\
\hline & $\mathrm{G} / \mathrm{G}(72)$ & $0.53(0.80)$ & $0.76(0.97)$ & $0.29(0.51)$ & $0.13(0.29)$ & $0.13(0.31)$ & $0.11(0.27)$ & $0.24(0.42)$ & $0.36(0.49)$ & $0.13(0.30)$ & $0.16(0.36)$ & $0.26(0.47)$ & $0.06(0.16)$ \\
\hline & $\mathrm{p}$ & 0.147 & 0.351 & 0.584 & 0.044 & 0.089 & 0.357 & 0.518 & 0.872 & 0.732 & 0.280 & 0.501 & 0.411 \\
\hline
\end{tabular}




\section{REFERENCES}

American Psychiatric Association., American Psychiatric Association. Task Force on DSM-IV., 1994. Diagnostic and statistical manual of mental disorders : DSM-IV, 4th ed. American Psychiatric Association, Washington, DC.

Anagnostou, E., Soorya, L., Chaplin, W., Bartz, J., Halpern, D., Wasserman, S., Wang, A.T., Pepa, L., Tanel, N., Kushki, A., Hollander, E., 2012. Intranasal oxytocin versus placebo in the treatment of adults with autism spectrum disorders: a randomized controlled trial. Mol Autism 3, 16. Anckarsater, H., Lundstrom, S., Kollberg, L., Kerekes, N., Palm, C., Carlstrom, E., Langstrom, N., Magnusson, P.K., Halldner, L., Bolte, S., Gillberg, C., Gumpert, C., Rastam, M., Lichtenstein, P., 2011. The Child and Adolescent Twin Study in Sweden (CATSS). Twin Res Hum Genet 14, 495-508. Anney, R., Klei, L., Pinto, D., Almeida, J., Bacchelli, E., Baird, G., Bolshakova, N., Bolte, S., Bolton, P.F., Bourgeron, T., Brennan, S., Brian, J., Casey, J., Conroy, J., Correia, C., Corsello, C., Crawford, E.L., de Jonge, M., Delorme, R., Duketis, E., Duque, F., Estes, A., Farrar, P., Fernandez, B.A., Folstein, S.E., Fombonne, E., Gilbert, J., Gillberg, C., Glessner, J.T., Green, A., Green, J., Guter, S.J., Heron, E.A., Holt, R., Howe, J.L., Hughes, G., Hus, V., Igliozzi, R., Jacob, S., Kenny, G.P., Kim, C., Kolevzon, A., Kustanovich, V., Lajonchere, C.M., Lamb, J.A., Law-Smith, M., Leboyer, M., Le Couteur, A., Leventhal, B.L., Liu, X.Q., Lombard, F., Lord, C., Lotspeich, L., Lund, S.C., Magalhaes, T.R., Mantoulan, C., McDougle, C.J., Melhem, N.M., Merikangas, A., Minshew, N.J., Mirza, G.K., Munson, J., Noakes, C., Nygren, G., Papanikolaou, K., Pagnamenta, A.T., Parrini, B., Paton, T., Pickles, A., Posey, D.J., Poustka, F., Ragoussis, J., Regan, R., Roberts, W., Roeder, K., Roge, B., Rutter, M.L., Schlitt, S., Shah, N., Sheffield, V.C., Soorya, L., Sousa, I., Stoppioni, V., Sykes, N., Tancredi, R., Thompson, A.P., Thomson, S., Tryfon, A., Tsiantis, J., Van Engeland, H., Vincent, J.B., Volkmar, F., Vorstman, J., Wallace, S., Wing, K., Wittemeyer, K., Wood, S., Zurawiecki, D., Zwaigenbaum, L., Bailey, A.J., Battaglia, A., Cantor, R.M., Coon, H., Cuccaro, M.L., Dawson, G., Ennis, S., Freitag, C.M., Geschwind, D.H., Haines, J.L., Klauck, S.M., McMahon, W.M., Maestrini, E., Miller, J., Monaco, A.P., Nelson, S.F., Nurnberger, J.I., Jr., Oliveira, G., Parr, J.R., Pericak-Vance, M.A., Piven, J., Schellenberg, G.D., Scherer, S.W., Vicente, A.M., Wassink, T.H., Wijsman, E.M., Betancur, C., Buxbaum, J.D., Cook, E.H., Gallagher, L., Gill, M., Hallmayer, J., Paterson, A.D., Sutcliffe, J.S., Szatmari, P., Vieland, V.J., Hakonarson, H., Devlin, B., 2012. Individual common variants exert weak effects on the risk for autism spectrum disorderspi. Hum Mol Genet.

Anney, R., Klei, L., Pinto, D., Regan, R., Conroy, J., Magalhaes, T.R., Correia, C., Abrahams, B.S., Sykes, N., Pagnamenta, A.T., Almeida, J., Bacchelli, E., Bailey, A.J., Baird, G., Battaglia, A., Berney, T., Bolshakova, N., Bolte, S., Bolton, P.F., Bourgeron, T., Brennan, S., Brian, J., Carson, A.R., Casallo, G., Casey, J., Chu, S.H., Cochrane, L., Corsello, C., Crawford, E.L., Crossett, A., Dawson, G., de Jonge, M., Delorme, R., Drmic, I., Duketis, E., Duque, F., Estes, A., Farrar, P., Fernandez, B.A., Folstein, S.E., Fombonne, E., Freitag, C.M., Gilbert, J., Gillberg, C., Glessner, J.T., Goldberg, J., Green, J., Guter, S.J., Hakonarson, H., Heron, E.A., Hill, M., Holt, R., Howe, J.L., Hughes, G., Hus, V., Igliozzi, R., Kim, C., Klauck, S.M., Kolevzon, A., Korvatska, O., Kustanovich, V., Lajonchere, C.M., Lamb, J.A., Laskawiec, M., Leboyer, M., Le Couteur, A., Leventhal, B.L., Lionel, A.C., Liu, X.Q., Lord, C., Lotspeich, L., Lund, S.C., Maestrini, E., Mahoney, W., Mantoulan, C., Marshall, C.R., McConachie, H., McDougle, C.J., McGrath, J., McMahon, W.M., Melhem, N.M., Merikangas, A., Migita, O., Minshew, N.J., Mirza, G.K., Munson, J., Nelson, S.F., Noakes, C., Noor, A., Nygren, G., Oliveira, G., Papanikolaou, K., Parr, J.R., Parrini, B., Paton, T., Pickles, A., Piven, J., Posey, D.J., Poustka, A., Poustka, F., Prasad, A., Ragoussis, J., Renshaw, K., Rickaby, J., Roberts, W., Roeder, K., Roge, B., Rutter, M.L., Bierut, L.J., Rice, J.P., Salt, J., Sansom, K., Sato, D., Segurado, R., Senman, L., Shah, N., Sheffield, V.C., Soorya, L., Sousa, I., Stoppioni, V., Strawbridge, C., Tancredi, R., Tansey, K., Thiruvahindrapduram, B., Thompson, A.P., Thomson, S., Tryfon, A., Tsiantis, J., Van Engeland, H., Vincent, J.B., Volkmar, F., Wallace, S., Wang, K., Wang, Z., Wassink, T.H., Wing, K., Wittemeyer, K., Wood, S., Yaspan, B.L., Zurawiecki, D., Zwaigenbaum, L., Betancur, C., Buxbaum, J.D., Cantor, R.M., Cook, E.H., Coon, H., Cuccaro, M.L., Gallagher, L., Geschwind, D.H., Gill, M., Haines, J.L., Miller, J., Monaco, A.P., Nurnberger, J.I., Jr., 
Paterson, A.D., Pericak-Vance, M.A., Schellenberg, G.D., Scherer, S.W., Sutcliffe, J.S., Szatmari, P., Vicente, A.M., Vieland, V.J., Wijsman, E.M., Devlin, B., Ennis, S., Hallmayer, J., 2010. A genome-wide scan for common alleles affecting risk for autism. Hum Mol Genet 19, 4072-4082.

Bailey, A., Le Couteur, A., Gottesman, I., Bolton, P., Simonoff, E., Yuzda, E., Rutter, M., 1995. Autism as a strongly genetic disorder: evidence from a British twin study. Psychol Med 25, 63-77.

Chakrabarti, B., Dudbridge, F., Kent, L., Wheelwright, S., Hill-Cawthorne, G., Allison, C., BanerjeeBasu, S., Baron-Cohen, S., 2009. Genes related to sex steroids, neural growth, and social-emotional behavior are associated with autistic traits, empathy, and Asperger syndrome. Autism Res 2, 157177.

Cho, M.M., DeVries, A.C., Williams, J.R., Carter, C.S., 1999. The effects of oxytocin and vasopressin on partner preferences in male and female prairie voles (Microtus ochrogaster). Behav Neurosci 113, 1071-1079.

Clark, C.L., St John, N., Pasca, A.M., Hyde, S.A., Hornbeak, K., Abramova, M., Feldman, H., Parker, K.J., Penn, A.A., 2013. Neonatal CSF oxytocin levels are associated with parent report of infant soothability and sociability. Psychoneuroendocrinology.

Constantino, J.N., Gruber, C.P., Davis, S., Hayes, S., Passanante, N., Przybeck, T., 2004. The factor structure of autistic traits. J Child Psychol Psychiatry 45, 719-726.

de Vries, G.J., 2008. Sex differences in vasopressin and oxytocin innervation of the brain. Prog Brain Res 170, 17-27.

Domes, G., Heinrichs, M., Kumbier, E., Grossmann, A., Hauenstein, K., Herpertz, S.C., 2013. Effects of Intranasal Oxytocin on the Neural Basis of Face Processing in Autism Spectrum Disorder. Biol Psychiatry.

Donaldson, Z.R., Young, L.J., 2008. Oxytocin, vasopressin, and the neurogenetics of sociality. Science 322, 900-904.

Duplan, S.M., Boucher, F., Alexandrov, L., Michaud, J.L., 2009. Impact of Sim1 gene dosage on the development of the paraventricular and supraoptic nuclei of the hypothalamus. Eur J Neurosci 30, 2239-2249.

Dworzynski, K., Ronald, A., Bolton, P., Happe, F., 2012. How different are girls and boys above and below the diagnostic threshold for autism spectrum disorders? J Am Acad Child Adolesc Psychiatry 51, 788-797.

Ebstein, R.P., Israel, S., Lerer, E., Uzefovsky, F., Shalev, I., Gritsenko, I., Riebold, M., Salomon, S., Yirmiya, N., 2009. Arginine vasopressin and oxytocin modulate human social behavior. Ann N Y Acad Sci 1167, 87-102.

Ebstein, R.P., Knafo, A., Mankuta, D., Chew, S.H., Lai, P.S., 2012. The contributions of oxytocin and vasopressin pathway genes to human behavior. Horm Behav 61, 359-379.

Guastella, A.J., Einfeld, S.L., Gray, K.M., Rinehart, N.J., Tonge, B.J., Lambert, T.J., Hickie, I.B., 2010. Intranasal oxytocin improves emotion recognition for youth with autism spectrum disorders. Biol Psychiatry 67, 692-694.

Hannelius, U., Gherman, L., Makela, V.V., Lindstedt, A., Zucchelli, M., Lagerberg, C., Tybring, G., Kere, J., Lindgren, C.M., 2007. Large-scale zygosity testing using single nucleotide polymorphisms. Twin Res Hum Genet 10, 604-625.

Hansson, S.L., Svanstrom Rojvall, A., Rastam, M., Gillberg, C., Anckarsater, H., 2005. Psychiatric telephone interview with parents for screening of childhood autism - tics, attention-deficit hyperactivity disorder and other comorbidities (A-TAC): preliminary reliability and validity. $\mathrm{Br} \mathrm{J}$ Psychiatry 187, 262-267.

Happe, F., Ronald, A., 2008. The 'fractionable autism triad': a review of evidence from behavioural, genetic, cognitive and neural research. Neuropsychol Rev 18, 287-304.

Higashida, H., Yokoyama, S., Munesue, T., Kikuchi, M., Minabe, Y., Lopatina, O., 2011. CD38 gene knockout juvenile mice: a model of oxytocin signal defects in autism. Biol Pharm Bull 34, 1369-1372. Hollander, E., Bartz, J., Chaplin, W., Phillips, A., Sumner, J., Soorya, L., Anagnostou, E., Wasserman, S., 2007. Oxytocin increases retention of social cognition in autism. Biol Psychiatry 61, 498-503. 
Hollander, E., Novotny, S., Hanratty, M., Yaffe, R., DeCaria, C.M., Aronowitz, B.R., Mosovich, S., 2003. Oxytocin infusion reduces repetitive behaviors in adults with autistic and Asperger's disorders.

Neuropsychopharmacology 28, 193-198.

Jamroziak, K., Szemraj, Z., Grzybowska-Izydorczyk, O., Szemraj, J., Bieniasz, M., Cebula, B., Giannopoulos, K., Balcerczak, E., Jesionek-Kupnicka, D., Kowal, M., Kostyra, A., Calbecka, M., Wawrzyniak, E., Mirowski, M., Kordek, R., Robak, T., 2009. CD38 gene polymorphisms contribute to genetic susceptibility to B-cell chronic lymphocytic leukemia: evidence from two case-control studies in Polish Caucasians. Cancer Epidemiol Biomarkers Prev 18, 945-953.

Jin, D., Liu, H.X., Hirai, H., Torashima, T., Nagai, T., Lopatina, O., Shnayder, N.A., Yamada, K., Noda, M., Seike, T., Fujita, K., Takasawa, S., Yokoyama, S., Koizumi, K., Shiraishi, Y., Tanaka, S., Hashii, M., Yoshihara, T., Higashida, K., Islam, M.S., Yamada, N., Hayashi, K., Noguchi, N., Kato, I., Okamoto, H., Matsushima, A., Salmina, A., Munesue, T., Shimizu, N., Mochida, S., Asano, M., Higashida, H., 2007. CD38 is critical for social behaviour by regulating oxytocin secretion. Nature 446, 41-45.

Knobloch, H.S., Charlet, A., Hoffmann, L.C., Eliava, M., Khrulev, S., Cetin, A.H., Osten, P., Schwarz, M.K., Seeburg, P.H., Stoop, R., Grinevich, V., 2012. Evoked axonal oxytocin release in the central amygdala attenuates fear response. Neuron 73, 553-566.

Kublaoui, B.M., Gemelli, T., Tolson, K.P., Wang, Y., Zinn, A.R., 2008. Oxytocin deficiency mediates hyperphagic obesity of Sim1 haploinsufficient mice. Mol Endocrinol 22, 1723-1734.

Larson, T., Anckarsater, H., Gillberg, C., Stahlberg, O., Carlstrom, E., Kadesjo, B., Rastam, M., Lichtenstein, P., 2010. The autism--tics, AD/HD and other comorbidities inventory (A-TAC): further validation of a telephone interview for epidemiological research. BMC Psychiatry 10, 1.

Lee, H.J., Macbeth, A.H., Pagani, J.H., Young, W.S., 3rd, 2009. Oxytocin: the great facilitator of life. Prog Neurobiol 88, 127-151.

Lichtenstein, P., Carlstrom, E., Rastam, M., Gillberg, C., Anckarsater, H., 2010. The genetics of autism spectrum disorders and related neuropsychiatric disorders in childhood. Am J Psychiatry 167, 13571363.

Ludwig, M., Leng, G., 2006. Dendritic peptide release and peptide-dependent behaviours. Nature reviews. Neuroscience 7, 126-136.

Lundstrom, S., Chang, Z., Kerekes, N., Gumpert, C.H., Rastam, M., Gillberg, C., Lichtenstein, P., Anckarsater, H., 2011. Autistic-like traits and their association with mental health problems in two nationwide twin cohorts of children and adults. Psychol Med 41, 2423-2433.

Lundstrom, S., Chang, Z., Rastam, M., Gillberg, C., Larsson, H., Anckarsater, H., Lichtenstein, P., 2012. Autism spectrum disorders and autistic like traits: similar etiology in the extreme end and the normal variation. Arch Gen Psychiatry 69, 46-52.

Ma, D., Salyakina, D., Jaworski, J.M., Konidari, I., Whitehead, P.L., Andersen, A.N., Hoffman, J.D., Slifer, S.H., Hedges, D.J., Cukier, H.N., Griswold, A.J., McCauley, J.L., Beecham, G.W., Wright, H.H., Abramson, R.K., Martin, E.R., Hussman, J.P., Gilbert, J.R., Cuccaro, M.L., Haines, J.L., Pericak-Vance, M.A., 2009. A genome-wide association study of autism reveals a common novel risk locus at $5 \mathrm{p} 14.1$. Ann Hum Genet 73, 263-273.

Mandy, W., Chilvers, R., Chowdhury, U., Salter, G., Seigal, A., Skuse, D., 2012. Sex differences in autism spectrum disorder: evidence from a large sample of children and adolescents. Journal of autism and developmental disorders 42, 1304-1313.

Michaud, J.L., DeRossi, C., May, N.R., Holdener, B.C., Fan, C.M., 2000. ARNT2 acts as the dimerization partner of SIM1 for the development of the hypothalamus. Mech Dev 90, 253-261.

Michaud, J.L., Rosenquist, T., May, N.R., Fan, C.M., 1998. Development of neuroendocrine lineages requires the bHLH-PAS transcription factor SIM1. Genes Dev 12, 3264-3275.

Modahl, C., Green, L., Fein, D., Morris, M., Waterhouse, L., Feinstein, C., Levin, H., 1998. Plasma oxytocin levels in autistic children. Biol Psychiatry 43, 270-277.

Munesue, T., Yokoyama, S., Nakamura, K., Anitha, A., Yamada, K., Hayashi, K., Asaka, T., Liu, H.X., Jin, D., Koizumi, K., Islam, M.S., Huang, J.J., Ma, W.J., Kim, U.H., Kim, S.J., Park, K., Kim, D., Kikuchi, M., Ono, Y., Nakatani, H., Suda, S., Miyachi, T., Hirai, H., Salmina, A., Pichugina, Y.A., Soumarokov, A.A., Takei, N., Mori, N., Tsujii, M., Sugiyama, T., Yagi, K., Yamagishi, M., Sasaki, T., Yamasue, H., Kato, N., 
Hashimoto, R., Taniike, M., Hayashi, Y., Hamada, J., Suzuki, S., Ooi, A., Noda, M., Kamiyama, Y., Kido, M.A., Lopatina, O., Hashii, M., Amina, S., Malavasi, F., Huang, E.J., Zhang, J., Shimizu, N., Yoshikawa, T., Matsushima, A., Minabe, Y., Higashida, H., 2010. Two genetic variants of CD38 in subjects with autism spectrum disorder and controls. Neurosci Res 67, 181-191.

Neumann, I.D., 2008. Brain oxytocin: a key regulator of emotional and social behaviours in both females and males. J Neuroendocrinol 20, 858-865.

Polzonetti, V., Carpi, F.M., Micozzi, D., Pucciarelli, S., Vincenzetti, S., Napolioni, V., 2012. Population variability in CD38 activity: correlation with age and significant effect of TNF-alpha -308G>A and CD38 184C>G SNPs. Molecular genetics and metabolism 105, 502-507.

Posserud, M.B., Lundervold, A.J., Gillberg, C., 2006. Autistic features in a total population of 7-9-yearold children assessed by the ASSQ (Autism Spectrum Screening Questionnaire). J Child Psychol Psychiatry 47, 167-175.

Riebold, M., Mankuta, D., Lerer, E., Israel, S., Zhong, S., Nemanov, L., Monakhov, M.V., Levi, S., Yirmiya, N., Yaari, M., Malavasi, F., Ebstein, R.P., 2011. All-trans retinoic acid upregulates reduced CD38 transcription in lymphoblastoid cell lines from Autism spectrum disorder. Mol Med 17, 799806.

Robinson, E.B., Koenen, K.C., McCormick, M.C., Munir, K., Hallett, V., Happe, F., Plomin, R., Ronald, A., 2011. Evidence that autistic traits show the same etiology in the general population and at the quantitative extremes (5\%, 2.5\%, and 1\%). Arch Gen Psychiatry 68, 1113-1121.

Ronald, A., Butcher, L.M., Docherty, S., Davis, O.S., Schalkwyk, L.C., Craig, I.W., Plomin, R., 2010. A genome-wide association study of social and non-social autistic-like traits in the general population using pooled DNA, $500 \mathrm{~K}$ SNP microarrays and both community and diagnosed autism replication samples. Behav Genet 40, 31-45.

Ronald, A., Larsson, H., Anckarsater, H., Lichtenstein, P., 2011. A twin study of autism symptoms in Sweden. Mol Psychiatry 16, 1039-1047.

Rosenberg, R.E., Law, J.K., Yenokyan, G., McGready, J., Kaufmann, W.E., Law, P.A., 2009.

Characteristics and concordance of autism spectrum disorders among 277 twin pairs. Arch Pediatr Adolesc Med 163, 907-914.

Sauer, C., Montag, C., Worner, C., Kirsch, P., Reuter, M., 2012. Effects of a common variant in the CD38 gene on social processing in an oxytocin challenge study: possible links to autism.

Neuropsychopharmacology 37, 1474-1482.

Swarbrick, M.M., Evans, D.S., Valle, M.I., Favre, H., Wu, S.H., Njajou, O.T., Li, R., Zmuda, J.M., Miljkovic, I., Harris, T.B., Kwok, P.Y., Vaisse, C., Hsueh, W.C., 2011. Replication and extension of association between common genetic variants in SIM1 and human adiposity. Obesity (Silver Spring) 19, 2394-2403.

Walum, H., Lichtenstein, P., Neiderhiser, J.M., Reiss, D., Ganiban, J.M., Spotts, E.L., Pedersen, N.L., Anckarsater, H., Larsson, H., Westberg, L., 2012. Variation in the oxytocin receptor gene is associated with pair-bonding and social behavior. Biol Psychiatry 71, 419-426.

Wang, K., Zhang, H., Ma, D., Bucan, M., Glessner, J.T., Abrahams, B.S., Salyakina, D., Imielinski, M., Bradfield, J.P., Sleiman, P.M., Kim, C.E., Hou, C., Frackelton, E., Chiavacci, R., Takahashi, N., Sakurai, T., Rappaport, E., Lajonchere, C.M., Munson, J., Estes, A., Korvatska, O., Piven, J., Sonnenblick, L.I., Alvarez Retuerto, A.I., Herman, E.I., Dong, H., Hutman, T., Sigman, M., Ozonoff, S., Klin, A., Owley, T., Sweeney, J.A., Brune, C.W., Cantor, R.M., Bernier, R., Gilbert, J.R., Cuccaro, M.L., McMahon, W.M., Miller, J., State, M.W., Wassink, T.H., Coon, H., Levy, S.E., Schultz, R.T., Nurnberger, J.I., Haines, J.L., Sutcliffe, J.S., Cook, E.H., Minshew, N.J., Buxbaum, J.D., Dawson, G., Grant, S.F., Geschwind, D.H., Pericak-Vance, M.A., Schellenberg, G.D., Hakonarson, H., 2009. Common genetic variants on 5p14.1 associate with autism spectrum disorders. Nature 459, 528-533.

Wang, Z., Young, L.J., De Vries, G.J., Insel, T.R., 1998. Voles and vasopressin: a review of molecular, cellular, and behavioral studies of pair bonding and paternal behaviors. Prog Brain Res 119, 483-499. Weiss, L.A., Arking, D.E., Daly, M.J., Chakravarti, A., 2009. A genome-wide linkage and association scan reveals novel loci for autism. Nature $461,802-808$. 
Xi, D., Gandhi, N., Lai, M., Kublaoui, B.M., 2012. Ablation of Sim1 neurons causes obesity through hyperphagia and reduced energy expenditure. PLoS One 7, e36453.

Yrigollen, C.M., Han, S.S., Kochetkova, A., Babitz, T., Chang, J.T., Volkmar, F.R., Leckman, J.F., Grigorenko, E.L., 2008. Genes controlling affiliative behavior as candidate genes for autism. Biol Psychiatry 63, 911-916.

Zafeiriou, D.I., Ververi, A., Vargiami, E., 2007. Childhood autism and associated comorbidities. Brain \& development 29, 257-272. 